\title{
A Review of Risk Management in Construction: Opportunities for Improvement
}

\author{
Rogério Cabral de Azevedoㅁ, Leonardo Ensslin², Antônio Edésio Jungles ${ }^{3}$ \\ ${ }^{1}$ Department of Civil Engineering - Federal Center of Technological Education (CEFET-MG), Belo Horizonte, Brazil \\ ${ }^{2}$ Pos-Graduate in Business Administration-UNISUL, Laboratory Methodologies in Multicriteria Decision \\ Support (LabMCDA), Belo Horizonte, Brazil \\ ${ }^{3}$ Department of Civil Engineering-PPGEC/UFSC, Laboratory Construction Management \\ (GestCon/ECV/UFSC), Belo Horizonte, Brazil \\ Email: rogerio@civil.cefetmg.br, leonardoensslin@gmail.com, ajungles@gmail.com
}

Received 21 February 2014; revised 20 March 2014; accepted 8 April 2014

Copyright (C) 2014 by authors and Scientific Research Publishing Inc.

This work is licensed under the Creative Commons Attribution International License (CC BY).

http://creativecommons.org/licenses/by/4.0/

(c) (i) Open Access

\section{Abstract}

To expand knowledge of a search on a particular topic or to gather a significant sample of information that allows the researcher to identify and analyze the current state of knowledge on a topic, this paper presents a structured process for the selection of academic papers, evidence of papers' relevance through bibliometric analysis, and analysis of the papers' contents to identify gaps in the knowledge related to the theme under consideration and the objectives of the researcher. Starting from an interest in identifying and analyzing valuation models and risk management applied to the construction industry and using the Knowledge Development Process-Constructivist (ProKnow-C), this research identified 12,032 articles in thirteen academic databases. In its subsequent steps, the ProKnow-C allowed, in a process of continuous selection, the choice of the 23 articles that presented quantitative or qualitative risk management models developed for the construction industry. The relevance of this set of papers was demonstrated by bibliometric analysis. The content of the articles was systematically analyzed from ten research lenses based on the concepts of risk, risk management, and performance measurement adopted by the researchers, representing their research vision. The results of the systematic analysis demonstrated that risk management is a broad and complex subject, especially when its management aims to both avoid/minimize risk and guide the organization to a level where the risks can be transformed into competitive advantages. The analysis revealed the unique character of risk perception, indicating that models developed in one context are suitable only for that context. Thus, the use of ProKnow-C facilitated the acquisition of knowledge and enabled the researcher to identify numerous research opportunities, which, if included in the development of a new model, would allow this 
model to be used as an instrument that is legitimate and valid for the measurement, assessment, and management of risk, enabling the company to achieve competitive advantages in the market.

\title{
Keywords
}

\author{
Risk Management, Construction, ProKnow-C
}

\section{Introduction}

Risk management has become an increasingly challenging activity. According to a global study by Ernst and Young, only 13\% of audit committee members classified the risk management of a company as effective. This same study emphasizes the need for the function of risk to be more than simply compliance with a bureaucratic exercise [1].

This situation is also apparent in the construction industry. The launch of a new project is considered a bet on a future often regarded as uncertain. The conception of a new venture project is considered the riskiest step because at this step, the ideal aspects of the project are defined, including its architectural and construction features, its target audience, and the marketing strategies used to reach this target audience. At this step, all necessary planning for the proposed aims is carried out and achieved. The decisions made at this stage have a significant impact on the achievement of the project goals [2]-[6].

The other features of a construction project must also be considered, including: 1) its nonhomogeneous character and nonserial production, a result of the uniqueness of the product, which is typically custom; 2) the implementation of the project in a dynamic, uncertain, and complex environment; 3) different stakeholders with positions that are not always convergent; 4) dependence on climatic factors during the construction process; 5) a long period of development; and 6) the division of responsibility among various companies. These various factors illustrate the actual and high degree of risk involved in the success of a project [7]-[10].

The above discussion illustrates the importance of planning that allows for the identification of the risks and anticipates their consequences, with the project becoming transparent, defensible, and demonstrably improved as decisions are made. The importance of planning is demonstrated by the various management methods used within construction and by specific methodologies for risk management [11]-[15].

However, these methodologies for risk management do not have structured processes for developing risk management models, leaving researchers and developers with the choice of tools and techniques to guide them in building their risk management models.

When we consider risk and its management as a success factor, it becomes clear that the perception of risk further complicates the problem.

Decision makers perceive the risks associated with a context differently based factors such as their experience, training, culture, personal beliefs and ways how risk events may affect her/his position in the company and/or career [3]. This diversity of perception makes decision making a matter of subjective judgment, based on intuition, personal experience, or internal company standards, rather than being based on a systematic review of the specific conditions of the project and market [16].

However, the majority of risk management models proposed for construction seeks its risk factors and assessment criteria in the external information sources to the assessed context, such as the literature, expert opinions, and/or academic sources.

In today's competitive environment, it is important for companies to have tools that are aligned with the strategic objectives of the organization and are suitable for changing circumstances. These tools must identify risks and measure the consequences, allowing for the creation of new ways to achieve the proposed goals and transform risky situations into sustainable competitive advantages [17] [18].

Such needs justify further research on the problem of how assessment and management models proposed for construction risks are developed and how these models address the unique aspects of risk perception.

According to Karlsson [19], one of the critical aspects of a survey is the scientific literature review, which helps the researcher to: 1) identify the current state of knowledge on a particular topic, giving scientific support for the researcher's work; 2) guide the construction of hypotheses and questions used in the study of the chosen 
topic, justifying the choice of topic and its contribution to the researcher's research proposal; 3) generate a detailed philosophical justification for the methodological framework used; and 4) develop skills for a critical analysis of the literature and for the treatment of extensive and dispersed information.

Thus, as initial step to examine how risk management models proposed for construction are situated relative to the problem under consideration, this research aims to: 1) provide a process for selecting a set of papers about risk management models proposed for construction; 2) highlight the relevance of the selected papers through a bibliometric analysis of the articles and their references, in what concerns with scientific recognition of articles, authors, journals and keywords; and 3) analyze how the selected papers address the unique aspects of risk perception.

The remainder of this paper is divided into six sections. The next section presents the ProKnow-C process, and the following section presents the methodological framework of this research. The third section presents the research process used in databases to select a set of papers. The fourth section presents the bibliometric process used for demonstrating the relevance of the set of papers, the fifth section presents the opportunities for research that were identified, and the sixth section presents the conclusions of this research.

\section{ProKnow-C}

To achieve the objectives discussed above, this research adopted the Knowledge Development Process - Constructivist (ProKnow-C) [20], which from the interest of the researcher in the issue, defines and sets out the restrictions intrinsic to the academic context, seeking to expand the researcher's knowledge so that he can conduct academic research with the stated reasons [18].

The ProKnow-C, similar to other systematic approaches to literature review, such as the Systematic Literature Review (SLR), is based on the definition of the limits to the selection (databases, keywords, temporal filters, and/or criteria for the inclusion or exclusion of papers), built from the researcher's knowledge and state-ofthe-art papers identified based on the issue under consideration [20] [21].

In this work, the ProKnow-C was used because it provides structured processes for the systematic review instead of having the researchers and developers choose the tools and techniques used to guide them in this task.

Moreover, the ProKnow-C has been used as a tool for building a robust and consistent theoretical framework by many researchers [22]-[32], justifying the choice of this instrument.

\section{Methodology}

The methodological framework consists of an examination, description, or explanation of the approaches and tools used in this research to specify the set of methods, procedures, and philosophical assumptions underlying the topic and providing an optical context under which the research was designed and performed [32].

Because the typology (methodology) research does not have a standard, the methodological framework to be adopted depends on the philosophical movement, goals outlined, researcher's perception, and expected results [33].

Thus, Table 1 aims to clarify the methodological framework used in this study according to the aspects described herein [34].

Table 1. Summary of the methodological framework.

\begin{tabular}{ll}
\hline View of knowledge & Constructivist \\
\hline Nature of the research object & Descriptive research \\
Nature of articles & Practical: case studies and experiments \\
Logical research & Deductive \\
Research process & Collecting data from secondary sources \\
Research results & Qualitative and quantitative approach \\
Technical procedures & Applied research \\
Intervention instrument & Bibliographic research \\
\hline
\end{tabular}




\section{Procedures for the Selection of Papers}

The ProKnow-C selects papers that will compose the bibliographic set based on three stages: 1) establishing research definitions; 2) conducting a preliminary investigation; and 3) selecting papers for the set [20].

\section{Research Definitions}

The definition of research axes is the first step in establishing research definitions using the ProKnow-C. Based on the proposed topic, this work adopts risk management in construction as the first axis of this research. For the second research axis, this work adopts performance assessment, in accordance with the aims of the research in identifying qualitative and/or quantitative risk management models for construction.

The second step consists of ordering the research chronologically. These procedures were performed in August 2011, with the next steps (i.e., the selection of articles and the bibliometric analysis) conducted in September, October, and November 2011. The procedure searched papers published in the 10 years preceding August 2011.

The adopted temporal filter (10 years) corresponds to the longer half-life of papers associated with civil engineering (the half-life of a paper is the number of years of its publication, calculated from the current year, comprising $50 \%$ of the total citations received by the journal in the current year) identified in a search conducted using JCR Science Edition [35].

The third step of establishing the research definitions is to identify the databases that will be accessed for consultation. For this work, we chose to consider all databases indexed by the CAPES website [36] and linked to the knowledge area "engineering”, subcategory "civil engineering”, that are provided in full free papers.

The final step consists of defining the search filters. The following items were used: keywords and publication type (papers). The main keywords were defined around the axes (i.e., performance evaluation and risk management). To facilitate the selection of risk management models proposed for construction, we included a third axis, represented by the keyword “construction”. Table 2 presents the keywords and respective axes.

The assertiveness of the proposed research definitions, particularly the keywords and databases, has been tested and approved according to the adhesion test proposed by the methodology adopted, ending this step.

\section{Selection of Papers for the Bibliographic Set}

After the validation of the research definitions, the process of selecting papers for the construction of bibliographic references was initiated. In addition to the keywords defined (Table 2) and the date of publication (2001 or later), excluding filters were applied when selecting the papers, according to the availability of this resource by the database's management system.

These filters were applied to the general topic of the papers, and the filters allowed for the exclusion of papers associated with areas related to health (e.g., medicine, dentistry, psychology, pharmacy), water (e.g., pollution and water resources), agriculture, biochemistry and genetics, social sciences, seismic phenomena, physics and astronomy, electricity (e.g., generation, transmission), metallurgy, and oil. The results of this process are shown in Table 3, sorted by the number of items obtained.

To effectively organize the papers taken from the databases, items were imported into the Endnote application [37], which allows for the identification of duplicate papers, books, conference papers, and reprints. These duplicate items were excluded.

Duplicate papers were found because of the following reasons: 1) two or more databases indexed the same journal and 2) the same paper was obtained from more than one combination of keywords. The bibliographic set consisted of 5561 items after the exclusion of duplicate papers and books.

Table 2. Keywords and axes.

SEARCH AXES

Construction

CONSTRUCTION
Risk Management

RISK
Performance Evaluation

ALLOCATION, ANALYSIS, APPRAISAL, ASSESSMENT, ATTITUDE,

EVALUATION, HANDLING, MANAGEMENT, MEASUREMENT

KEYWORDS 
Table 3. Search by papers (using keywords) in the selected databases (2001-2011), ordered by number of papers in descending order.

\begin{tabular}{clcc}
\hline N & \multicolumn{1}{c}{ Database } & Qty papers & CUSUM \\
\hline 1 & Scopus (Elsevier) & 4.072 & 4.072 \\
2 & Compendex (Engineering Village 2) & 2.221 & 6.293 \\
3 & Web of Science & 1.454 & 7.747 \\
4 & Maney Publishing & 902 & 8.649 \\
5 & CSA Technology Research Database & 870 & 9.519 \\
6 & ScienceDirect & 794 & 10.313 \\
7 & American Society of Civil Engineers-ASCE & 567 & 10.880 \\
8 & API Scitation (American Institute of Physics) & 484 & 11.364 \\
9 & Wiley Online Library & 302 & 11.666 \\
10 & Applied Science Full Text (Wilson) & 168 & 11.834 \\
11 & Institution of Civil Engineers-ICE & 110 & 11.944 \\
12 & SciELO.org & 88 & 12.032 \\
13 & SpringerLink (MetaPress) & - & 12.032 \\
\hline
\end{tabular}

The next step consisted of selecting papers by aligning the titles, which identified duplicate papers not detected in the previous step. These papers (72), which were duplicated because of differences in the spelling of the name of the author or the title, were excluded.

The analysis of the alignment of the title allowed for the identification of 5005 papers with titles that were not aligned with the research aim. These papers were excluded from the bibliographic set, which subsequently included 556 articles (gross base papers, not repeated and aligned with the research aim).

Next, the 556 papers of the bibliographic set were analyzed for scientific recognition. This analysis was performed based on the number of citations that each paper had received since its publication, obtained through Google Scholar [38] and sorted in descending order.

To identify the most relevant papers (most cited), a cutoff value corresponding to $85 \%$ of the total sum of citations of the 556 papers was set. This limit was based on the Pareto postulate, which states that most of the effect originates from a small number of causes. In the context of this research, this postulate states that the most cited articles (minority) will represent most of the scientific recognition in the current bibliographic set.

The 556 papers had a total of 5152 citations. The cutoff value was 4379 citations, considering the representativeness of $85 \%$. Thus, with the items sorted in descending order of the number of individual citations, the papers were selected until the value of the accumulated citations was equal to the cutoff value. This selection occurred for a paper with 10 citations.

Because the lower limit was set (papers with 10 citations), all items with more than nine citations were selected to compose the bibliographic set (gross base papers, not repeated and with the title aligned with the research aim and scientific recognition). After this process, the bibliographic set included 138 papers.

The 418 least-cited papers would still go through a review process involving other criteria and could be integrated into the final bibliographic set of papers selected. Thus, in the next step, the 138 papers in the bibliographic set were assessed to determine whether the abstract aligned with the research aim. This analysis resulted in the exclusion of 55 papers. After this step, the bibliographic set included 83 papers (gross base papers, not repeated and with the title and abstract aligned with the research aim).

As previously mentioned, the set of 418 least-cited articles (not considered due to the criterion of scientific recognition) was the subject of a new review process. In this process, the article could be integrated into the bibliographic set if it had been published within less than two years of the analysis (papers that have not yet had the opportunity to be cited) and was written by some of the authors already present in the 83 selected papers.

According to these criteria, 127 papers published in 2009, 2010, and 2011 were identified among the least 
cited. Of this group, 72 papers had authors who were listed in the 83 selected papers (bibliographic set). These 72 papers were assessed for alignment of the abstract with the research aim, which resulted in the inclusion of 62 new papers. Thus, the bibliographic set included 145 papers.

The search for the full text of the papers resulted in the exclusion of 36 papers because they were not available in full on the CAPES website [36].

After reading the full text of the remaining 109 papers, seven papers were identified that were not aligned with the research aim (and were thus excluded) and two papers were excluded because they were considered reprints (the version with higher number of citations was kept in the final set).

Of the 100 remaining papers in the bibliographic set, 23 papers were identified that presented qualitative and/or quantitative risk management models for construction, with processes for risk identification and measurement of the consequences of risk, compatible with the aim of this research.

Table 4 presents a summary of the selection process of papers for the construction of the theoretical framework (bibliographic set), and Table 5 lists the 23 selected papers, in alphabetical order by first author.

\section{Bibliometric Analysis of the Bibliographic Set}

A bibliometric analysis of the bibliographic set of papers that comprises the theoretical framework about risk management models used in construction is based on the quantitative evidence of statistical data for the management of information and scientific knowledge of a given subject, conducted by a document count [20], and includes the following steps:

- Identify the degree of relevance of the journals;

- Identify the scientific recognition of the papers;

- Identify the relevance degree of the authors of the papers; and

- Identify the most commonly used keywords.

To illustrate the bibliometric analysis of the bibliographic set, the most relevant analysis of the first two items, i.e., the degree of relevance of the journals and the scientific recognition of the papers, is displayed.

The main analysis of the first item considers the count of papers published by each journal within the bibliographic set and the count of each journal in the bibliographic references of the set. An analysis of the journals that published the selected papers illustrates that 1) the International Journal of Project Management includes five papers in the set; 2) Automation in Construction includes four papers; and 3) the Journal of Construction, Engineering and Management includes three papers. Table 6 summarizes this analysis.

The second analysis, i.e., the bibliometric analysis of bibliographic references, indicates that 309 references had been cited by the 23 selected papers in the bibliographic set. Of these 309 references, the ten most relevant journals for the references are shown in Figure 1.

The second analysis, which identifies the scientific recognition of the 23 selected papers, was performed by counting the number of citations that each article has received since its publication. As illustrated in Figure 2, this analysis highlights the following articles: 1) Carr and Tah [39] — A fuzzy approach to construction project risk assessment and analysis: Construction project risk management system-with 83 citations; 2) Chapman

Table 4. Papers included in each step of the selection process.

\begin{aligned} & \hline Papers Step of the ProKnow-C process \\ & \hline $\mathbf{1 2 , 0 3 2}$ Extraction of papers from databases \\ & $\mathbf{5 5 6 1}$ Elimination of redundancy (duplicate papers) \\ & $\mathbf{5 5 6}$ Papers with titles that were aligned with the research aim \\ & $\mathbf{1 3 8}$ Papers with scientific recognition (cutoff value of 85\%) \\ & $\mathbf{8 3}$ Papers with abstracts that were aligned with the research aim \\ & $\mathbf{1 4 5}$ Inclusion of recent papers (least cited) from authors already selected \\ & $\mathbf{1 0 9}$ Papers with full text available \\ & $\mathbf{2 3}$ Papers that were fully aligned with the research aim (presenting qualitative and/or quantitative risk management models) \\ & \hline\end{aligned}


Table 5. Papers selected for the bibliographic set (alphabetically).

ABDELGAWAD, M. \& FAYEK, A. R. Fuzzy reliability analyzer: Quantitative assessment of risk events in the construction industry using fuzzy fault-tree analysis. Journal of Construction Engineering and Management, v.137, n.Compendex, p.294-302. 2011.

BU-QAMMAZ, A. S., DIKMEN, I. \& BIRGONUL, M. T. Risk assessment of international construction projects using the analytic network process. Canadian Journal of Civil Engineering, v.36, n.7, July, p.1170-81. 2009

CARR, V. \& TAH, J. H. M. A fuzzy approach to construction project risk assessment and analysis: Construction project risk management system. Advances in Engineering Software, v.32, n.Compendex, p.847-857. 2001.

CHAPMAN, R. J. The controlling influences on effective risk identification and assessment for construction design management. International Journal of Project Management, v.19, n.3, p.147-160. 2001.

CHOI, H.-H. \& MAHADEVAN, S. Construction project risk assessment using existing database and project-specific information. Journal of Construction Engineering and Management, v.134, n.Compendex, p.894-903. 2008.

DEY, P. K. Decision support system for risk management: a case study. Management Decision, v.39, n.8, p.634-649. 2001.

DEY, P. K. Managing project risk using combined analytic hierarchy process and risk map. Applied Soft Computing Journal, v.10, n.Compendex, p.990-1000. 2010.

DIKMEN, I. \& BIRGONUL, M. T. An analytic hierarchy process based model for risk and opportunity assessment of international construction projects. Canadian Journal of Civil Engineering, v.33, n.1, January, p.58-68. 2006.

DIKMEN, I., BIRGONUL, M. T. \& GUR, A. K. A case-based decision support tool for bid mark-up estimation of international construction projects. Automation in Construction, v.17, n.1, p.30-44. 2007.

DIKMEN, I., BIRGONUL, M. T. \& HAN, S. Using fuzzy risk assessment to rate cost overrun risk in international construction projects. International Journal of Project Management, v.25, n.Compendex, p.494-505. 2007.

HAN, S. H., KIM, D. Y., KIM, H. \& JANG, W. S. A web-based integrated system for international project risk management. Automation in Construction, v.17, n.3, p.342-356. 2008.

HSUEH, S. L., PERNG, Y. H., YAN, M. R. \& LEE, J. R. On-line multi-criterion risk assessment model for construction joint ventures in China. Automation in Construction, v.16, n.5, p.607-619. 2007

KARTAM, N. A. \& KARTAM, S. A. Risk and its management in the Kuwaiti construction industry: A contractors' perspective. International Journal of Project Management, v.19, n.Compendex, p.325-335. 2001.

SHANG, H., ANUMBA, C. J., BOUCHLAGHEM, D. M., MILES, J. C., CEN, M. \& TAYLOR, M. An intelligent risk assessment system for distributed construction teams. Engineering, Construction and Architectural Management, v.12, n.Compendex, p.391-409. 2005.

TAH, J. H. M. \& CARR, V. Towards a framework for project risk knowledge management in the construction supply chain. Advances in Engineering Software, v.32, n.Compendex, p.835-846. 2001.

TANG, L. C. M., LEUNG, A. Y. T. \& WONG, C. W. Y. Entropic risk analysis by a high level decision support system for construction SMEs. Journal of Computing in Civil Engineering, v.24, n.Compendex, p.81-94. 2010.

THOMAS, A. V., KALIDINDI, S. N. \& GANESH, L. S. Modelling and assessment of critical risks in BOT road projects. Construction Management and Economics, v.24, n.Compendex, p.407-424. 2006.

XIANG, Y., LIU, C., ZHANG, K. \& WU, Q. Risk analysis and management of submerged floating tunnel and its application. Procedia Engineering, v.4, p.107-116. 2010.

XU, Y., YEUNG, J. F. Y., CHAN, A. P. C., CHAN, D. W. M., WANG, S. Q. \& KE, Y. Developing a risk assessment model for PPP projects in China -- A fuzzy synthetic evaluation approach. Automation in Construction, v.19, n.7, p.929-943. 2010.

ZAYED, T., AMER, M. \& PAN, J. Assessing risk and uncertainty inherent in Chinese highway projects using AHP.

International Journal of Project Management, v.26, n.Compendex, p.408-419. 2008.

ZAYED, T. M. \& CHANG, L. M. Prototype model for build-operate-transfer risk assessment. Journal of Management in Engineering, v.18, n.1, Jan, p.7-16. 2002.

ZENG, J., AN, M. \& SMITH, N. J. Application of a fuzzy based decision making methodology to construction project risk assessment. International Journal of Project Management, v.25, n.Compendex, p.589-600. 2007.

ZHANG, G. M. \& ZOU, P. X. W. Fuzzy analytical hierarchy process risk assessment approach for joint venture construction projects in China. Journal of Construction Engineering and Management-ASCE, v.133, n.10, Oct, p.771-779. 2007. 
Table 6. Relevance of the journals.

\begin{tabular}{lcc}
\hline \multicolumn{1}{c}{ JOURNAL } & Number of papers & SNIP* $^{*}$ \\
\hline International Journal of Project Management & 5 & 1.935 \\
Automation in Construction & 4 & 2.309 \\
Journal of Construction Engineering and Management & 3 & 1.939 \\
Canadian Journal of Civil Engineering & 2 & 0.619 \\
Advances in Engineering Software & 2 & 1.777 \\
Procedia Engineering & 1 & 0.496 \\
Management Decision & 1 & 1.081 \\
Journal of Management in Engineering & 1 & 1.705 \\
Journal of Computing in Civil Engineering & 1 & 1.348 \\
Engineering Construction and Architectural Management & 1 & 0.647 \\
Construction Management and Economics & 1 & 0.912 \\
Applied Soft Computing Journal & 1 & 3.449 \\
\hline
\end{tabular}

"SNIP (Source Normalized Impact per Paper)—www.journalmetrics.com/ (2011).

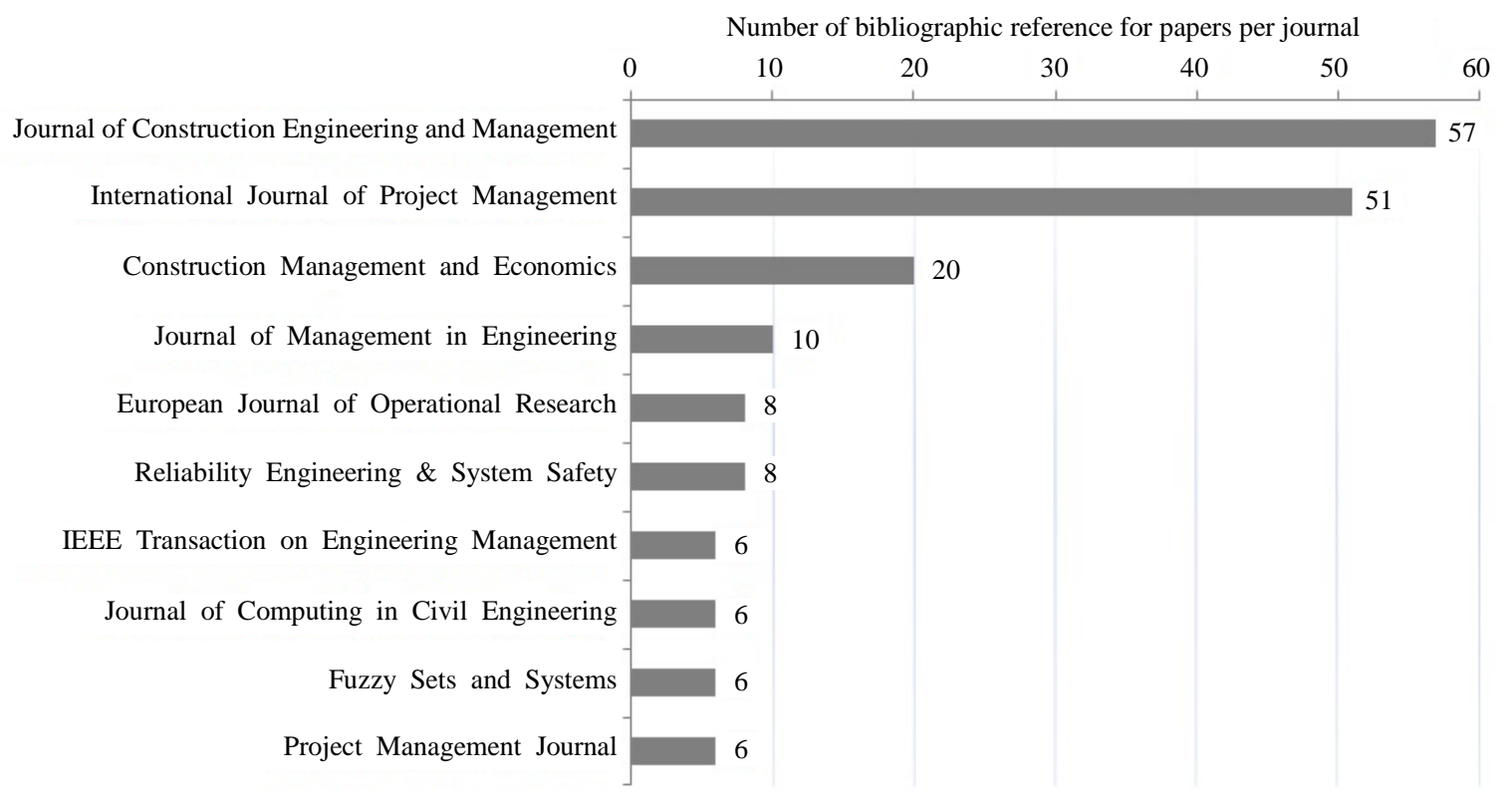

Figure 1. Relevance of the references in the bibliographic set.

[40]_-The controlling influences on effective risk identification and assessment for construction design management-with 72 citations; and 3) Dey [41]—Decision support system for risk management: a case studywith 51 citations.

The relevance of the articles that compose the theoretical framework can also be emphasized by considering the rank of the set to which the journals belong, which is provided by CAPES [42]. This analysis illustrates that 17 of the 23 papers (73\%) were published by journals classified in the first three degrees of quality (degrees A1, A2, and B1). Similarly, 10 of the 12 journals (83\%) that published the 23 papers are ranked in the first three degrees of quality (degrees A1, A2, and B1).

\section{Systematic Analysis of the Selected Papers}

The systematic analysis advocated by ProKnow-C [20] is defined as a scientific process used to analyze a 


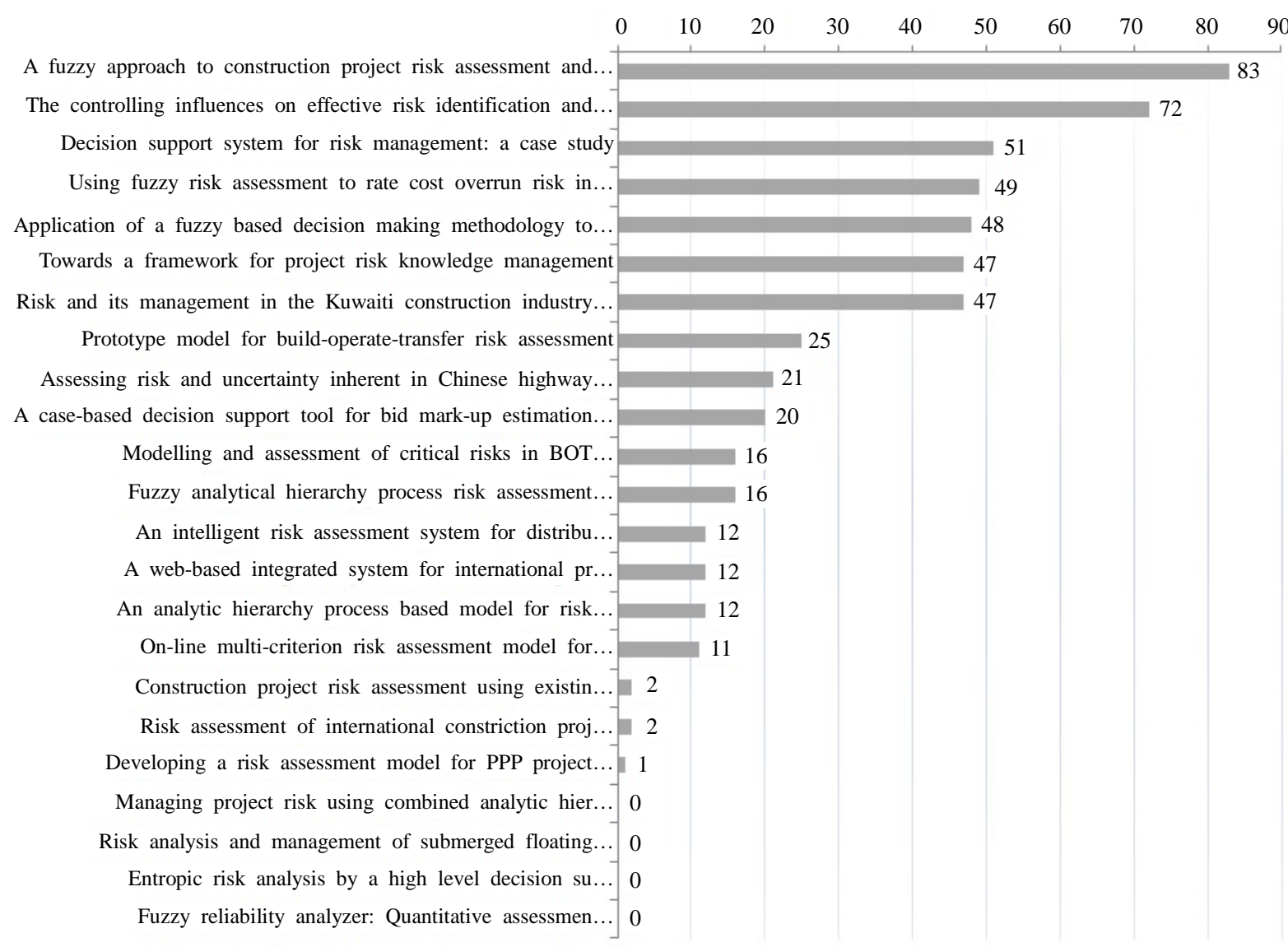

Figure 2. Relevance of papers according to scientific recognition.

representative sample of selected papers according to the research vision (research lenses) adopted by the researchers, to identify the strengths and weaknesses of knowledge found in the sample for each lens and all lenses.

The systematic analysis is composed of the following steps: 1) identification of the criteria for the analysis; 2) analysis of the content of each article according to each of the analysis criteria; and 3) analysis of the overall results, with each criterion forming an axis of review.

The first item, the identification of the criteria for the analysis (or the research lenses) is based on the definitions of risk and risk management proposed by PMBOK [13] and the definition of performance evaluation, proposed by Ensslin et al. [43]. These concepts and the criteria derived from them are shown in Table 7, Table 8, respectively.

In the second item, the 23 selected papers were analyzed separately according to the ten research lenses. To respond to the third item, i.e., the analysis of the papers according to the axes of the evaluation, the results obtained in the analysis performed in the second item were organized, and each of these criteria now corresponds to an axis of the evaluation.

The process of systematic analysis of articles is exemplified in lenses 1 (Risk), 3 (Approach to solving problems), 5 (Method for identifying risks), and 8 (Mensuration) and summarized in Table 9.

\subsection{Concept of Risk (Lens 1)}

Although the concept of risk adopted by most authors considers the positive or negative effects of risk on project objectives, most of the tools developed to date are used only to measure and assess threats (negative effects); opportunities (positive effects) are generally not covered by these tools [44].

Identifying and utilizing opportunities that may be provided by the market is as important as identifying and avoiding threats. Whereas identifying and avoiding threats can allow potential losses to be minimized or avoided, identifying and utilizing opportunities allows profits to be maximized. 
Table 7. Concepts used to define the evaluation criteria

1. Concept of risk [13]

"Risk is an uncertain event or condition that, if it occurs, has a positive or negative effect on the project objectives".

2. Concept of risk management [13]

"It is the systematic process of identifying, analyzing, and responding to project risks. It includes maximizing the probability and consequences of positive events and minimizing the probability and consequences of adverse events to project objectives and is divided into six steps: planning, risk identification, qualitative risk analysis, quantitative risk analysis, risk response planning, and risk monitoring and control".

3. Concept of performance evaluation [43]

"Performance evaluation is the process of building the decision maker's knowledge regarding the specific context in which he is proposed to evaluate, from the perception of the decision maker himself through activities that identify, organize, measure ordinally and cardinally, and integrate and still provide the ways to visualize the impact of their actions and foster its management".

Table 8. Research lenses used in the systematic analysis of the literature.

\begin{tabular}{|c|c|c|c|}
\hline ID & Lens & What search? & Source $^{1}$ \\
\hline 1 & Risk & $\begin{array}{l}\text { Does the concept of risk covered by the paper recognize the positive and } \\
\text { negative effects of risk? }\end{array}$ & 1 \\
\hline 2 & Risk management & What is the theoretical affiliation of risk management adopted by the paper? & 2 \\
\hline 3 & Approach & $\begin{array}{l}\text { What approach to problem solving is adopted, and what type of development } \\
\text { is adopted for the model built? }\end{array}$ & 3 \\
\hline 4 & Singularity & Does it recognize the uniqueness of the evaluated context? & 3 \\
\hline 5 & Method for identifying risks & $\begin{array}{l}\text { What is the process used to identify risks? Is it identified according to the } \\
\text { perception of the decision maker? }\end{array}$ & 3 \\
\hline 6 & Independence & $\begin{array}{l}\text { Does the process consider the dependence between the evaluation criteria or } \\
\text { test the independence of these criteria? }\end{array}$ & 2 e 3 \\
\hline 7 & Axes of measurement & What are the axes along which the risk criteria are measured? & 2 \\
\hline 8 & Mensuration & Does it recognize the properties of ordinal scales? & 3 \\
\hline 9 & Integration & Does the integration process recognize the need for reference levels? & 3 \\
\hline 10 & Improvement & $\begin{array}{l}\text { Does the constructed model consider the current situation to allow for the generation } \\
\text { of improvement actions and the monitoring of these actions' consequences? }\end{array}$ & 2 e 3 \\
\hline
\end{tabular}

${ }^{1}$ Concept of risk (1); Concept of risk management (2); Concept of performance evaluation (3).

A passive strategy relative to opportunities is certainly less effective than acting proactively with advanced planning that will allow for an increase in the likelihood and beneficial effects of opportunities.

However, only two papers [44] [45] address the positive effects of risks (opportunities) in the developed models. The risk management models presented in the other selected articles only consider threats (negative effects caused by risk).

Thus, future research should develop a risk management model that 1 ) identifies the positive and negative impacts of risk, making these impacts a strategic factor for success and 2) transforms risk into an opportunity, making plans and response strategies to generate competitive advantages in the market.

\subsection{Approach to Solving Problems (Lens 3)}

Four approaches to solving problems are identified in the literature on decision support [46]:

- Descriptive: this approach is characterized by describing what happens in the world without making human judgments on this reality. Such approaches are instruments that originate from the natural sciences and are appropriate when human interpretation is irrelevant;

- Normative: this approach is characterized by the adoption of models that have worked in other contexts and are believed by decision makers to be applicable to their context without adjustments. The involvement of the manager is summarized as the choice of the model to be implemented; 
Table 9. Research opportunities identified in the systematic analysis. Source: Authors.

\begin{tabular}{|c|c|c|c|}
\hline ID & Lens & ${ }^{*}$ QTY Models & Opportunity: Developing a model for assessing and managing risks that ... \\
\hline 1 & Risk & 2 & $\begin{array}{l}\text { (i) identify both the negative and positive impacts of risk, making these impacts a } \\
\text { strategic factor for success; and } \\
\text { (ii) allow for the creation of response plans and strategies to transform the risk into } \\
\text { competitive advantages in the market. }\end{array}$ \\
\hline 2 & Risk management & 7 & $\begin{array}{l}\text { address strategic, tactical, and operational issues; consider the company, enterprise, } \\
\text { and market; and consider the values and preferences of those who are responsible } \\
\text { for decisions. }\end{array}$ \\
\hline 3 & Approach & 7 & $\begin{array}{l}\text { adopt a constructivist perspective, develop this perspective, and apply the perspective } \\
\text { to the same context to properly reflect the values and preferences of the decision maker } \\
\text { and the context itself, which will be modified by the decisions taken. }\end{array}$ \\
\hline 4 & Singularity & 7 & $\begin{array}{l}\text { ensure that the decision maker considers the support tools for risk management to be } \\
\text { representative of their values and preferences, creating alignment, consistency, and } \\
\text { assertiveness in decisions. }\end{array}$ \\
\hline 5 & $\begin{array}{l}\text { Method for } \\
\text { identifying risks }\end{array}$ & 7 & $\begin{array}{l}\text { have the criteria identified according to the vision of the decision maker (values and } \\
\text { preferences) regarding the decision context. }\end{array}$ \\
\hline 6 & Independence & 6 & $\begin{array}{l}\text { have an approach to the identification of criteria and the mapping of cause and effect } \\
\text { that identify its dependent relationships or ensure its independence. }\end{array}$ \\
\hline 7 & Axes of measurement & 2 & have axes of measurement that can simplify or facilitate the operation of the model. \\
\hline 8 & Mensuration & - & $\begin{array}{l}\text { have processes to transform ordinal scales into cardinal scales that consider reference } \\
\text { levels and are conducted in accordance with the value judgments of the decision maker. }\end{array}$ \\
\hline 9 & Integration & - & $\begin{array}{l}\text { (i) establish an understanding of the contribution of each criterion to the overall } \\
\text { assessment; (ii) recognize the need to measure the goals pursued by the decision } \\
\text { maker and not the alternatives that are available to him; and (iii) recognize the } \\
\text { need for reference levels for the decision maker to compare criteria. }\end{array}$ \\
\hline 10 & Improvement & 4 & $\begin{array}{l}\text { implement the proposed improvement actions with continuous monitoring of the } \\
\text { consequences of these actions, creating the necessary foundations for the model to } \\
\text { be used as a tool for risk management. }\end{array}$ \\
\hline
\end{tabular}

*Number of models proposed in the 23 analyzed papers that heed, completely or partially, the questions represented by the lens of research.

- Prescriptive: this approach is characterized by the adaptation and personalization of management models for a given organization with the guidance of an outside expert. This approach considers that the processes must be customized and that the organization must be involved in providing information and subsequently adopting the recommendations given by the outside expert;

- Constructivist: this approach seeks to develop interactively a coherent body of knowledge with the decision maker, enabling the decision maker to understand the consequences of his decisions on those factors that the decision maker thinks necessary and sufficient.

In the selected papers, the adoption of a prescriptive approach in which the author relies on external views, such as the literature, the opinions of professionals with extensive experience, and/or academic opinions, for the context of the risk assessment model is predominant in the bibliographic set (used in 19 papers; [5] [16] [39] [44] [45] [47]-[60]).

However, among these papers, Dikmen et al. [45] and Choi et al. [60] also adopt a descriptive approach, using the results of previous projects developed by the company under consideration as the basis for their models.

Four papers use the constructivist approach, which uses the context itself (projects and views of the stakeholders involved) as the basis for the risk management model as well as tools for expanding knowledge (such as decision trees, fault trees, and decision diagrams) [40] [41] [61] [62].

Regarding the application of the model, there are four different types of development:

- The model is constructed and applied in the same context, and although the model can employ external points of view, it is built based on the preferences of the stakeholders [41] [45] [47] [53] [56] [61] [62];

- The model is built in one context and applied in another, and the stakeholders linked to the context are limited to the application of the model developed [5] [16] [48]-[51] [55];

- The model is built in one context, but there are no reports of its application [40] [57]; 
- The model is built in one context and adapted to another context [39] [44] [52] [54] [58]-[60].

The environment of the construction industry is characterized by its uniqueness, complexity, uncertainty, limited information, and conflicts due to the presence of many stakeholders with views that do not always converge, thus leading to a high degree of risk and subjective decisions [2] [6] [16] [47] [63] [64]; thus, this work proposes the adoption of the constructivist approach by accepting the need for obtaining new knowledge for the manager that can increase his understanding of the context in which he is involved and that his decisions will influence.

Similarly, this work considers that only a model built and implemented in the same context can properly reflect the values and preferences of the decision maker and the context itself, which will be modified by the decisions that he makes.

Thus, the opportunity arises to present a risk management model that is built under the constructivist perspective and applied in the same context in which it was developed.

\subsection{Method for Identifying Risks (Lens 5)}

The bibliographic set includes several instruments for addressing how to identify the necessary risk factors and the sufficiency of the evaluation for a given context.

Most papers identify the risk factors in the scientific literature (14 papers):

- (4) four papers review the criteria identified in the literature using questionnaires answered by professionals with extensive experience in the topic (experts) [5] [16] [45] [50];

- (2) two papers review the criteria identified in the literature through workshops with professionals with extensive experience [54] [55].

- (8) The remaining eight papers review evaluation criteria directly in the scientific literature [39] [44] [48] [51] [52] [57]-[59].

Nine papers in the bibliographic set use the following instruments to identify the evaluation criteria:

- (1) Historical data from previous projects of the organization itself [60];

- (1) Questionnaires for professionals and recognized experts with knowledge on the topic [49];

- (1) Questionnaires with stakeholders involved in the project [53];

- (3) Brainstorming sessions with stakeholders involved in the project [41] [56] [61];

- (3) Workshops with stakeholders involved in the project [40] [47] [62].

Figure 3 summarizes the methods used to identify the evaluation criteria.

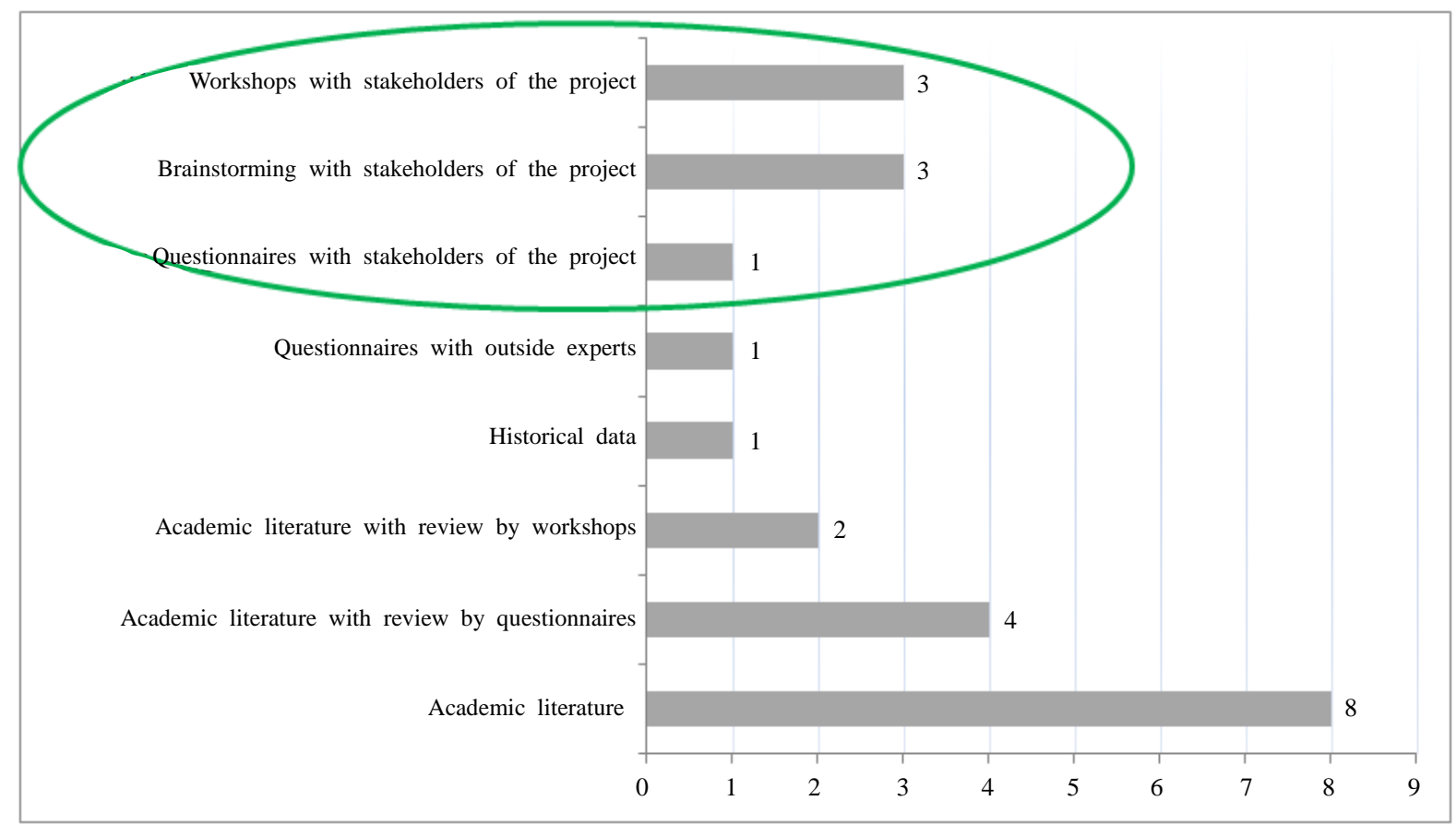

Figure 3. Methods for identifying the evaluation criteria. 
The analysis of methods used to identify the evaluation criteria used in risk assessment models indicates research opportunities for constructing risk management models with criteria that are identified in accordance with the vision of the decision maker (values and preferences) regarding the evaluation context.

\subsection{Mensuration (Lens 8)}

Once the evaluation criteria for the risk assessment have been identified, the manner in which the directions of preference for each axis are identified, or how the measurement scales are built, is established.

Ordinal scales are widely used in the selected papers, and 18 papers use a specific type of ordinal scale, the Likert scale (where the scale values are represented by linguistic variables, ordered to represent attractiveness of a goal or issue) to measure the evaluation criteria [16] [39] [40] [45] [47]-[50] [52]-[59] [61] [62].

Four articles use both ordinal scales (representing absolute values) and Likert scales [5] [41] [51] [60].

One paper uses ordinal scales representing relative values (percentages) for the mensuration of probability and impact [44].

Likert scales (ordinal) are easily constructed but the theory of measurement [43] [65] implies that the scales must satisfy six properties to be scientifically valid:

- Measurability;

- Operationality;

- Homogeneity;

- Intelligibility;

- Distinction between the best and worst performance; and

- Respect for the properties of ordinal scales.

Recognizing this limitation, ten papers in the bibliographic set using processes to transform the ordinal scales into cardinal scales to expand the understanding of the context by allowing a given level of risk of a criterion to be compared to the same level of risk for another criterion [5] [16] [41] [44] [49] [50] [52] [54] [56] [57] [62].

Using the knowledge provided by cardinal scales, we have the opportunity to provide a process for the integration of scales without disregarding the limits of ordinal scales, which are used for mathematical operations of frequency, count, median, and mode [65].

However, in these 10 papers, the processing is performed without defining reference levels to equalize what is considered normal or optimal performance, which can be seen as a restriction when compared to pairwise comparisons [66].

Thus, future research should investigate the use of processes to transform ordinal scales into cardinal scales that consider reference levels and are conducted in accordance with the value judgments of the decision maker.

\subsection{Research Opportunities}

The procedures performed in the systematic analysis facilitated the identification of opportunities for research in the development of risk management models and the methods used to develop these models. These opportunities are presented in Table 9 .

\section{Conclusions}

Given the importance of academic research for building knowledge in the researcher, enabling him to identify the current state of knowledge on a topic and facilitating the construction of hypotheses and research questions that will guide the development of his research, this work presents a structured process for academic research for composition of a theoretical framework (ProKnow-C). This process ensures the creation of a bibliographic set of comprehensive, representative, and relevant papers on risk management models developed for construction.

The procedures of the ProKnow-C [20], in its first stage, allowed the researchers to select from a gross sample of 12,032 papers, among which the 23 most relevant papers presented qualitative and/or quantitative models for risk management in construction.

These procedures highlighted the current state of academic knowledge on the topic of research, allowing the researcher to obtain new knowledge that was further supported by the identification of journals and authors who stood out in publications on the topic based on bibliometric analyses of the items in the bibliographic set.

The bibliometric analyses, the second step of ProKnow-C (2010), which are based on statistical analyses, 
identified the journals that stood out in the publications on the topic and in their references. The "International Journal of Project Management" and "Journal of Construction, Engineering and Management" are among the top 3 journals based on the publications on the topic and in their references.

In relation to the authors of the papers, the bibliometric analyses identified two authors that were featured in publications on the topic: Diekmen, I. and Birnogul, M. T., both of whom are authors on four of the 23 selected papers.

The third step of the ProKnow-C [20], the systematic analysis of the papers, was performed from the researchers' perspective of knowledge. This perspective is structured as ten research lenses (Table 8), which are based on the concepts of risk and risk management proposed by PMBOK [13] and performance evaluation by Ensslin et al. [43].

The concept of performance evaluation had been adopted because the researchers recognized the need to generate knowledge that enables the decision maker to evaluate the context that will be modified by their decisions (constructivist approach) and the implicit acceptance of the uniqueness of risk perception, which is evaluated and measured as a function of the decision maker's own values and preferences.

The results of the systematic analysis highlighted the fact that risk management is a broad and complex subject, especially when management seeks to both avoid or minimize risks and guide the organization to a level at which some of these risks can be turned into competitive advantages in the market. Furthermore, the unique nature of risk perception makes models developed in a particular context suitable only for that context.

The adoption of the constructivist process (ProKnow-C) allowed the proposed objectives in the introduction of this research to be met, namely 1) provide a process for selecting references (bibliographic set) for risk management models in construction; 2) highlight the relevance of the set through a bibliometric analysis of the papers, references, authors, and journals; and 3) analyze the selected papers that address the unique aspects of risk perception.

The use of these procedures facilitated the acquisition of knowledge, answered the question initially proposed in this research, and enabled the researchers to identify several research opportunities. If such opportunities had been incorporated into a risk management model for construction, the opportunities would allow the model developed for use as a tool for risk management, allowing competitive advantages to be realized in the market.

We believe that this study will contribute to future studies based on structured processes for the selection and presentation of papers, authors, and journals most relevant to a given topic, creating a consistent theoretical framework for the support of future research. Using these same structured processes, the research opportunities identified from the systematic analysis of the content of the selected papers will create a foundation for the research objectives.

As a proposal for future work, we suggest the adoption of constructivist methodologies, such as Multicriteria Decision Aid-Constructivist Methodology (MCDA-C), which was proposed by Ensslin et al. [67], to develop risk management models for the construction industry. These models will allow the research opportunities reported in this work to be achieved and will thus contribute to the advancement of risk management in construction.

This study is not without limitations; in particular, two limitations are (1) the definition of the sample field of research because only papers with full texts that were available from the periodic system of CAPES in October 2011 were considered [25] and (2) the unique context of the systematic review process because these limitations are based on the judgment of the researchers and linked to their values, preferences, and prior knowledge.

\section{References}

[1] SEBRAE (2010) Apenas 13\% das Empresas Têm Gestão de Risco Eficaz. Auditoria Interna do Sistema SEBRAE.

[2] Buzzi, D.C. (2010) Diretrizes para o Gerenciamento de Risco em Incorporadoras da Construção Civil: Uma Abordagem Utilizando Lógica Difusa, in Programa de Pos Graduação em Engenharia Civil. UFSC, Florianópolis.

[3] Wang, J. and Yuan, H. (2010) Factors Affecting Contractors’ Risk Attitudes in Construction Projects: Case Study from China. International Journal of Project Management, 29, 209-219. http://dx.doi.org/10.1016/j.ijproman.2010.02.006

[4] Correa, P.S. (2010) O Papel das Incorporadoras e das Construtoras na Construção Civil Brasileira. Palestra-FGV UNICOC-Fundação Getúlio Vargas, Ribeirão Preto.

[5] Hsueh, S.L., et al. (2007) On-Line Multi-Criterion Risk Assessment Model for Construction Joint Ventures in China. Automation in Construction, 16, 607-619. http://dx.doi.org/10.1016/j.autcon.2007.01.001 
[6] Lam, K., et al. (2007) Modelling Risk Allocation Decision in Construction Contracts. International Journal of Project Management, 25, 485-493. http://dx.doi.org/10.1016/j.ijproman.2006.11.005

[7] Kern, A.P. and Formoso, C.T. (2006) A Model for Integrating Cost Management and Production Planning and Control in Construction. Journal of Financial Management of Property and Construction, 11, 75-90. http://dx.doi.org/10.1108/13664380680001081

[8] Liu, L. and Zhu, K. (2007) Improving Cost Estimates of Construction Projects Using Phased Cost Factors. Journal of Construction Engineering and Management, 133, 91-95. http://dx.doi.org/10.1061/(ASCE)0733-9364(2007)133:1(91)

[9] Hoffmann, V.E., Procopiak, J.A. and Rossetto, C.R. (2008) As estratégias de influência dos stakeholders nas organizações da indústria da construção civil: setor de edificações em Balneário Camboriú—SC. Revista Ambiente Construído, Porto Alegre, 8, 21-35.

[10] Yang, J.-B. and Peng, S.-C. (2008) Development of a Customer Satisfaction Evaluation Model for Construction Project Management. Building and Environment, 43, 458-468. http://dx.doi.org/10.1016/j.buildenv.2006.07.044

[11] CMMI, P.T. (2006) CMMI® for Development, Version 1.2-Improving Processes for Better Products. S.E. Institute, Editor, Carnegie Mellon University, Pittsburgh.

[12] FERMA (2003) Norma de Gestão de Riscos. Federation of European Risk Management Associations, Brussels.

[13] PMBOK (2008) Um guia do conjunto de conhecimentos em gerenciamento de projetos. $4^{\text {a }}$ Edição Edition, PMIProject Management Institute, Inc.

[14] RAMP (2004) Risk Analysis and Management for Projects. ICE-Institution of Civil Engineers, Faculty of Actuaries, and Institute of Actuaries, London.

[15] AS/NZS:4360 (2004) The Australian and New Zealand Standard on Risk Management, AS/NZS 4360: 2004, in Risk Management. Sidney.

[16] Han, S.H., et al. (2008) A Web-Based Integrated System for International Project Risk Management. Automation in Construction, 17, 342-356. http://dx.doi.org/10.1016/j.autcon.2007.05.012

[17] Keeney, R.L. (1996) Value-Focused Thinking: A Path to Creative Decisionmaking. Harvard University Press, Harvard.

[18] Lacerda, R.T.O., Ensslin, L. and Ensslin, S.R. (2012) Uma Análise Bibliométrica da Literatura Sobre Estratégia e Avaliação De Desempenho. Gestão \& Produção, 1, 59-78.

[19] Karlsson, C. (2008) Researching Operations Management. Taylor \& Francis, New York.

[20] Ensslin, L., et al. (2010) ProKnow-C, Knowledge Development Process-Construtivist. Processo técnico com patente de registro pendente junto ao INPI. Brazil.

[21] Codinhoto, R., et al. (2008) The Effects of the Built Environment on Health Outcomes. The Health and Care Infrastructure Research and Innovation Centre.

[22] Azevedo, R.C., et al. (2011) Avaliação de desempenho do processo de orçamento: estudo de caso em uma obra de construção civil. Revista Ambiente Construído, Porto Alegre, 11, 85-104. http://dx.doi.org/10.1590/S1678-86212011000100007

[23] Lacerda, R.T.O., Ensslin, L. and Ensslin, S.R. (2014) Research Opportunities in Strategic Management Field: A Performance Measurement Approach. Int. Journal Business Performance Management, 15, 158-174.

[24] Ensslin, S.R., et al. (2014) Evidenciação do estado da arte da avaliação da segurança do trabalho em empreendimentos da construção civil. Interciencia, 39, 16-23.

[25] Azevedo, R.C. ( 2013) A Model for Risk Management in Property Development Using Multicriteria Desion AidConstructivist Methodology (MCDA-C). PPGEC, UFSC, Florianopolis.

[26] Azevedo, R.C., et al. (2013) Performance Measurement to Aid Decision Making in the Budgeting Process for Apartment Building Construction: A Case Study Using MCDA-C. Journal of Construction Engineering and Management, 139, 225-235.

[27] Ensslin, L., Ensslin, S.R. and Pacheco, G.C. (2012) Um estudo sobre segurança em estádios de futebol baseado na análise bibliométrica da literatura internacional. Perspectivas em Ciência da Informação, 17, 71-91. http://dx.doi.org/10.1590/S1413-99362012000200006

[28] Afonso, M.H.F., et al. (2012) Como construir conhecimento sobre o tema de pesquisa? Aplicação do processo PROKNOW-C na busca de literatura sobre avaliação do desenvolvimento sustentável. Revista de Gestão Social $e$ Ambiental, 5, 47-62.

[29] Da Rosa, F.S., et al. (2012) Envirnonmental Disclosure Management: A Construtivist Case. Management Decision, 50, 1117-1136. http://dx.doi.org/10.1108/00251741211238364

[30] Vilela, L.O. (2012) Aplicação do PROKNOW-C para seleção de um portifólio bibliográfico e análise bibliométrica 
sobre avaliação de desempenho da gestão do conhecimento. Revista Gestão Industrial, 8, 76-92.

[31] Bortoluzzi, S.C., Ensslin, S.R. and Ensslin, L. (2011) Avaliação de desempenho multicritério como apoio à gestão de empresas: Aplicação em uma empresa de serviços. Gestão \& Produção, 18, 633-650. http://dx.doi.org/10.1590/S0104-530X2011000300014

[32] Tasca, J.E., et al. (2010) An Approach for Selecting a Theoretical Framework for the Evaluation of Training Programs. Journal of European Industrial Training, 34, 631-655. http://dx.doi.org/10.1108/03090591011070761

[33] PETRI, S.M. (2005) Modelo para apoiar a avaliação das abordagens de gestão de desempenho e sugerir aperfeiçoamentos: Sob a ótica construtivista. Universidade Federal de Santa Catarina, Florianópolis.

[34] Ensslin, L. and Ensslin, S.R. (2008) Notas de aula. Disciplina de Avaliação de Desempenho do Programa de Pós Graduação em Engenharia da Produção. UFSC.

[35] JCR. Journal Citation Reports-JCR Science Edition. Subject Categories CONSTRUCTION \& BUILDING TECHNOLOGY; ENGINEERING, CIVIL 2011. http://admin-apps.webofknowledge.com/JCR/JCR?RQ=RECORD\&journal=CIVIL+ENG\&rank=24\#cited_hlife.

[36] CAPES (2012) Portal de Periódicos CAPES. http://www.periodicos.capes.gov.br/?option=com_phome\&Itemid=68\&

[37] Reuters, T. (2009) EndNote X3. The Thomson Corporation.

[38] Google (2011) Google Acadêmico. http://scholar.google.com.br/

[39] Carr, V. and Tah, J.H.M. (2001) A Fuzzy Approach to Construction Project Risk Assessment and Analysis: Construction Project Risk Management System. Advances in Engineering Software (Compendex), 32, 847-857.

[40] Chapman, R.J. (2001) The Controlling Influences on Effective Risk Identification and Assessment for Construction Design Management. International Journal of Project Management, 19, 147-160. http://dx.doi.org/10.1016/S0263-7863(99)00070-8

[41] Dey, P.K. (2001) Decision Support System for Risk Management: A Case Study. Management Decision, 39, $634-649$. http://dx.doi.org/10.1108/00251740110399558

[42] CAPES (2012) WebQualis-Classificação de Periódicos por Estrato. http://qualis.capes.gov.br/webqualis/principal.seam

[43] Ensslin, L., Giffhorn, E., Ensslin, S.R. Petri, S.M. and Vianna, W.B. (2010) Avaliação do desempenho de empresas terceirizadas com o uso da metodologia multicritério de apoio à decisão-construtivista. Pesquisa Operacional, 30, 125-152. http://dx.doi.org/10.1590/S0101-74382010000100007

[44] Dikmen, I. and Birgonul, M.T. (2006) An Analytic Hierarchy Process Based Model for Risk and Opportunity Assessment of International Construction Projects. Canadian Journal of Civil Engineering, 33, 58-68. http://dx.doi.org/10.1139/105-087

[45] Dikmen, I., Birgonul, M.T. and Gur, A.K. (2007) A Case-Based Decision Support Tool for Bid Mark-Up Estimation of International Construction Projects. Automation in Construction, 17, 30-44. http://dx.doi.org/10.1016/j.autcon.2007.02.009

[46] Roy, B. (1994) On Operational Research and Decision Aid. European Journal of Operational Research, 73, $23-26$. http://dx.doi.org/10.1016/0377-2217(94)90136-8

[47] Zeng, J., An, M. and Smith, N.J. (2007) Application of a Fuzzy Based Decision Making Methodology to Construction Project Risk Assessment. International Journal of Project Management, 25, 589-600. http://dx.doi.org/10.1016/j.ijproman.2007.02.006

[48] Kartam, N.A. and Kartam, S.A. (2001) Risk and Its Management in the Kuwaiti Construction Industry: A Contractors' Perspective. International Journal of Project Management (Compendex), 19, 325-335.

[49] Zayed, T.M. and Chang, L.M. (2002) Prototype Model for Build-Operate-Transfer Risk Assessment. Journal of Management in Engineering, 18, 7-16. http://dx.doi.org/10.1061/(ASCE)0742-597X(2002)18:1(7)

[50] Zayed, T., Amer, M. and Pan, J. (2008) Assessing Risk and Uncertainty Inherent in Chinese Highway Projects Using AHP. International Journal of Project Management (Compendex), 26, 408-419.

[51] Thomas, A.V., Kalidindi, S.N. and Ganesh, L.S. (2006) Modelling and Assessment of Critical Risks in BOT Road Projects. Construction Management and Economics (Compendex), 24, 407-424.

[52] Zhang, G.M. and Zou, P.X.W. (2007) Fuzzy Analytical Hierarchy Process Risk Assessment Approach for Joint Venture Construction Projects in China. Journal of Construction Engineering and Management-Asce, 133, 771-779. http://dx.doi.org/10.1061/(ASCE)0733-9364(2007)133:10(771)

[53] Shang, H., et al. (2005) An Intelligent Risk Assessment System for Distributed Construction Teams. Engineering, Construction and Architectural Management (Compendex), 12, 391-409.

[54] Bu-Qammaz, A.S., Dikmen, I. and Birgonul, M.T. (2009) Risk Assessment of International Construction Projects 
Using the Analytic Network Process. Canadian Journal of Civil Engineering, 36, 1170-1181. http://dx.doi.org/10.1139/L09-061

[55] Xu, Y., et al. (2010) Developing a Risk Assessment Model for PPP Projects in China-A Fuzzy Synthetic Evaluation Approach. Automation in Construction, 19, 929-943. http://dx.doi.org/10.1016/j.autcon.2010.06.006

[56] Dey, P.K. (2010) Managing Project Risk Using Combined Analytic Hierarchy Process and Risk Map. Applied Soft Computing Journal (Compendex), 10, 990-1000.

[57] Xiang, Y., Liu, C., Zhang, K. and Wu, Q.Q. (2010) Risk Analysis and Management of Submerged Floating Tunnel and Its Application. Procedia Engineering, 4, 107-116. http://dx.doi.org/10.1016/j.proeng.2010.08.013

[58] Tang, L.C.M., Leung, A.Y.T. and Wong, C.W.Y. (2010) Entropic Risk Analysis by a High Level Decision Support System for Construction SMEs. Journal of Computing in Civil Engineering (Compendex), 24, 81-94.

[59] Tah, J.H.M. and Carr, V. (2001) Towards a Framework for Project Risk Knowledge Management in the Construction Supply Chain. Advances in Engineering Software (Compendex), 32, 835-846.

[60] Choi, H.H. and Mahadevan, S. (2008) Construction Project Risk Assessment Using Existing Database and Project-Specific Information. Journal of Construction Engineering and Management (Compendex), 134, 894-903.

[61] Dikmen, I., Birgonul, M.T. and Han, S. (2007) Using Fuzzy Risk Assessment to Rate Cost Overrun Risk in International construction projects. International Journal of Project Management (Compendex), 25, 494-505.

[62] Abdelgawad, M. and Fayek, A.R. (2011) Fuzzy reliability analyzer: Quantitative assessment of risk events in the construction Industry Using Fuzzy Fault-Tree Analysis. Journal of Construction Engineering and Management (Compendex), 137, 294-302.

[63] Corrêa, L. (2008) Gestão de Projetos aplicados à construção civil. Revista IETEC-Instituto de Educação Tecnológica, Belo Horizonte, Brasil.

[64] Fan, M., Lin, N.P. and Sheu, C. (2008) Choosing a Project Risk-Handling Strategy: An Analytical Model. International Journal of Production Economics, 112, 700-713. http://dx.doi.org/10.1016/j.ijpe.2007.06.006

[65] Barzilai, J. (2001) On the Foundations of Measurement. Proceedings of the 2001 IEEE International Conference on Systems, Man and Cybernetics, Tucson, 7-10 October, 2001, 401-406.

[66] Lacerda, R.T.O., Ensslin, L. and Ensslin, S.R. (2011) A Performance Measurement View of IT Project Management. International Journal of Productivity and Performance Management, 60, 132-151. http://dx.doi.org/10.1108/17410401111101476

[67] Ensslin, L., et al. (2012) Software Process Assessment and Improvement Using Multicriteria Decision Aiding-Constructivist. Journal of Information Systems and Technology Management, 9, 473-496. 